\title{
Influence of Price Volatility on Herding Behaviour: A Study of Nigerian Stock Market
}

\author{
Ifeoma Patricia Osamor ${ }^{{ }^{*}}$ Edwin C. Anene ${ }^{2}$ \\ 1.Department of Accounting, Faculty of Management Sciences, Lagos State University, Lagos State, Nigeria \\ 2.Department of Management and Accounting, Faculty of Management Sciences, Ladoke Akintola University of \\ Technology, Oyo State, Nigeria
}

\begin{abstract}
Price volatility in the stock market could lead to irrational behaviour of investors which might tantamount result into herding behaviour. This study evaluated the influence of price volatility on herding behaviour in Nigerian stock market with focus on Consumer goods, Financial services, Health care and Industrial goods sectors. Monthly data of stock prices for fifteen years from $2001-2015$ were used and 97 companies' stocks from the four sectors were considered. OLS model was used to determine the existence and extent of herding behaviour in these sectors. The results showed that price volatility had influence on herding behaviour, but there was no evidence of herding noticed in any of the sectors, except Financial services sector which was not statistically significant. The study recommended that NSE should make information available to all market participants in order to boost their confidence in making investment decisions.
\end{abstract}

Keywords: Herding behavior; Price volatility; Nigerian Stock Market; Stock price

DOI: $10.7176 /$ RJFA/10-10-09

Publication date:May $31^{\text {st }} 2019$

\section{Introduction}

Price volatility in the stock market is an issue of concern. Prices of stocks are assumed to adjust to new information in the stock market, therefore volatility can be said to occur by the continuous adjustment of stock prices to new information and accurate measurement of this, forms the basis of investment, pricing model and market efficiency. Stock market efficiency is one of the factors that determine economic growth; therefore, the stock market can be regarded as the engine of economic growth. Yadav (2017) defined the stock market as a hub where facilities are provided to the investors to purchase and sell their shares, bonds and debenture. In other words, stock market is a platform for trading various securities and derivatives without any barriers. According to Ohiomu and Enabulu (2011) "stock market as a public market where company stocks and derivatives are traded at an agreed price". In the stock market, investors are regarded as rational human being who make investment decisions based on risk and the associated returns from that investment. According to the 'Prospect Theory' of Kahneman and Tversky (1979), it states that decisions are not always optimal, it is the willingness to take risk that determine the way decisions are made, but Ouarda, Abdelfatteh and Olivero (2013) suggested that it is important not to place too much concentration on investors and their rationality only, but also to introduce a variable of irrationality into the prospect theory in order to show that it is not only the willingness to take risk that determines the way decisions are made, it could also be as a result of herding behaviour.

Herding behaviour is often used in literature to describe the co-movement of members in a group without a planned direction (Kim, Lee, Choi \& Ahn, 2013). The mimicking tendency of investors termed as herding results in investors buying and selling same or similar stocks in large numbers over a period of time (Ganesh \& Naresh, 2016). It is a way of imitating how the other person buys or sells shares and implementing that in one's portfolio in order to feel more secure. When investors herd, they show a willingness to downplay the importance of their own information and evaluation in favour of the aggregate market consensus (Tran \& Huy, 2011). Researches on developed and developing markets around the world have shown that the movement in stock price could influence investors' behaviour which might lead to herding behaviour (Tran \& Huy, 2011; Ouarda, et al., 2013; Kim, et al., 2013). The effects of price volatility on investors' behaviour in Nigerian stock market is an issue of concern since the market is regarded as highly volatile, therefore, this study wants to investigate the influence of price volatility on herding behaviour in Nigerian stock markets.

\section{Literature Review}

\subsection{Herding and Volatility}

The relationship between investors' behaviour and price volatility was first discovered by Friedman (1953). It was found that irrational investors destabilized prices by buying when prices were high and selling when they were low, while rational investors buy low and sell high. Wang (1993) observed that uneven information may cause volatility and investors that are not well informed tend to follow the market trend, buying when prices rise and selling when they fall; a behavior that can be regarded as herding. This behaviour could also be rational; in a rational perspective, a herding behavior is likened to a situation where the investors have tried to redress their 
performances and their reputations by ignoring voluntarily their own analyses and to reproduce another manager who possesses a source of more reliable information or the analysis competencies of more eminent decisions (Ouarda, et al., 2013).

\subsection{Theoretical Review}

This study is based on the capital asset pricing model (CAPM). It was developed in mid-1960s by Sharpe (1964), Lintner (1965) and Mossin (1966). Consequently, the model is often referred to as Sharpe-Lintner-Mossin Capital Asset Pricing Model. CAPM was developed when the theoretical foundations of decision making under uncertainty were moderately new and empirical facts about return and risk in the stock markets were unknown (Perold, 2004). Oseni and Olanrewaju (2017) described the CAPM as one of the early risk management models which has remained a principal ornament for modelling modern financial economics. Rossi (2016) described it as a useful tool for estimating the cost of capital for firms and the returns that investors require in investing in a company's assets. The CAPM explains the trade-off between assets' returns and their risks, measuring the risk of an asset as the covariance of its returns with returns on the overall market.

The model (CSAD) for detecting herding behaviour was derived by Chang, Cheng and Khorana (2000) from the conditional version of CAPM. Chiang and Zheng (2010) stated that according to the Capital Asset Pricing Model (CAPM), there is a linear relationship between return dispersion of individual company's stock and return on market portfolio, but when different market conditions exist, investors may react in a more uniform manner, exhibiting herding behaviour which brings about a non-linear market return.

\subsection{Empirical Studies}

The existence and measure of herding in stock markets is distinguished on two categories of measuring herding based on the nature of the defined data. The basis for the first measures is investors' portfolio's composition and investors' transaction flow, while the second category focuses on herding as a whole and this indicates collective behaviour of all market participants.

Lakonishok, Shleifer and Vishny (1992) empirically examined the patterns of trading of institutional investors by concentrating on the frequency of herding and positive-feedback trading, which are related to the general notion that institutional investors disrupt stock prices. 769 all-equity tax-exempt funds which is predominantly pension funds were sampled and evaluated; these funds were managed by 341 institutional money managers in the United State. The result shows that there is a little evidence of herding among pension fund managers when trading in large stocks (those in the top two quintiles by market capitalization), which indicates over 95\% concentration of their trading. Evidence of herding was found in smaller stocks, but the extent is far from dramatic. Also, the estimations of the study of Walter (2006) based on 60 mutual funds specialized in shares German declare that herding is a little higher than the ones gotten from other developed financial markets.

Christie and Huang (1995) made used of Cross-Sectional Standard Deviation (CSSD) which they derived to measure herding. Data on daily returns of stocks listed on the NYSE and Amex for July 1962 to December 1988 were used and the results show that herding occurs when the market is under stress, i.e. when an individual investor possibly ignore their own information and evaluation and go with the market consensus. Chang et. al. (2000) also made used of their derived technique which is the Cross-Sectional Absolute Deviation (CSAD) and studied markets in the U.S., Hong Kong, South Korea, Taiwan and Japan. They discovered that herding does not take place in the U.S. and Hong Kong, little trace of herding in Japan, but significant proof of herding in South Korea and Taiwan. Chiang and Zheng (2010) used daily data of industrial stock returns to study herding behaviour of 18 countries which are United States, Australia, France, Germany, Hong Kong, Japan, the United Kingdom, Argentina, Brazil, Chile, Mexico, China, South Korea, Taiwan, Indonesia, Malaysia, Singapore, and Thailand for May 25, 1988 to April 24, 2009. Contrary to previous studies that evidence of herding was not seen in advanced markets (Chang et al. 2000; Demirer \& Kutan, 2006), they discovered significant evidences supporting the existence of herding in all the national markets except the US and Latin America.

Lakshman, Basu and Vaidyanathan, (2011) concluded that Indian investors are better informed and behave rationally since there is no significant evidence of herding in Indian stock markets. In contrast to Christie and Huang (1995), they suggested that herding can be more pronounce before market stress, rather than during market stress since market crisis can lead to market equilibrium. Contrary to the results of Chang et al. (2000) who discovered herding in emergent economies such as South Korea and Taiwan; Prosad, Kapoor and Sengupta (2012) used daily data of fifty (50) from the period of April 2006 to March 2011 and did not find herding in the Indian stock market. Nevertheless, individual tests for bull and bear periods of the market show that herding is detected in larger degree in bull period. These findings are in support of the results of Lao and Singh (2011). Ahsan and Sarkar (2013) examined herding in Dhaka Stock Exchange (DSE) in Bangladesh for a period of seven years. Daily and monthly returns for all stocks listed on the Dhaka Stock Exchange were used and there was no existence of herding in Dhaka Stock Exchange for the period studied. 


\section{Methodology and Data Description}

\subsection{Foundation of Estimated Model}

The model for analysing herding behaviour during period of price volatility was adopted from the work of Ouarda, et al. (2013) which is in line with the study made by Chiang and Zheng (2010). The Cross-Sectional Absolute Deviation (CSAD) which measures returns dispersion was used to identify herding behaviour. The $\mathrm{CSAD}_{\mathrm{t}}$ is stated below:

$$
C S A D_{t}=\frac{1}{N} \sum_{i=1}^{N}\left|R_{i, t}-R_{m, t}\right|
$$

Where $\mathrm{R}_{\mathrm{i}, \mathrm{t}}$ is the observed stock return of industry $i$ at time $\mathrm{t}, \mathrm{R}_{\mathrm{m}, \mathrm{t}}$ is the cross-sectional average stock of $\mathrm{N}$ returns in the portfolio at time $t$ and $\mathrm{N}$ is the number of firms in the portfolio. The model (CSAD) for detecting herding behaviour was derived by Chang, et al. (2000) from the conditional version of CAPM which stipulated that there is a linear relationship between the return dispersion of individual company stock and the return of market portfolio. This model was adapted by Ouarda, et al. (2013). For this study, the adapted model by Ouarda, et al. (2013) will be adopted to determine the existence of herding behaviour in Nigerian stock market.

\subsection{Herding Behaviour and Price Volatility}

According to Gleason, Mathur and Peterson (2004), herding is more pronounced during periods characterized by abnormal volatility. This perception is supported by Ouarda, et al. (2013) who discovered that herding behavior is more likely to be spread during months characterized by strong volatilities in European financial market. The potential effects of asymmetric herding behaviour in relation to price volatility is measured by using the understated approach.

$$
\begin{aligned}
& \operatorname{CSAD}_{\mathrm{i}, \mathrm{t}}=\gamma_{0}+\gamma_{1} \mathrm{D}^{\text {Hvolatilty }}\left|\mathrm{R}_{\mathrm{m}, \mathrm{t}}\right|+\gamma_{2}\left(1-\mathrm{D}^{\text {Hvolatilty }}\right)\left|\mathrm{R}_{\mathrm{m}, \mathrm{t}}\right|+\gamma_{3} \mathrm{D}^{\text {Hvolatilty }} \mathrm{R}_{\mathrm{m}, \mathrm{t}}+\gamma_{4}\left(1-\mathrm{D}^{\text {Hvolatilty }}\right) \\
& \mathrm{R}^{2}{ }_{\mathrm{m}, \mathrm{t}}+\varepsilon
\end{aligned}
$$

Where $\mathrm{D}^{\text {Hvolatilty }}$ is a dummy variable which takes the value 1 during the month of high volatility and 0 otherwise. Market volatility is assumed to be high if it exceeds the weighted average of the volatilities of six months preceding our study period and vice versa.

\subsection{Data}

To determine the existence of herding behaviour during the price volatility, the study made used of 97 stocks' returns from four sectors in the Nigerian stock exchange with a monthly frequency from January, 2001 to December, 2015. The criteria for choosing the 97 stocks from the total of 118 stocks listed in these sectors are the stocks that are consistently listed on the Nigerian stock exchange, companies that are still actively trading on the floor of the Nigerian stock exchange, those that traded most on the Nigerian stock market and they have more than $50 \%$ of total market capitalization. The methodology stated above are applied on the group of stocks on the basis of sector classification in the Nigerian stock exchange. The 97 company stocks are already classified into 4 sectors by the Nigerian stock exchange as Consumer Goods, Financial Services, Healthcare and Industrial Goods. The monthly stock returns are determined by applying the formula $R_{i, t}=\underline{P}_{i, t}-\underline{P}_{0, t}$

$P_{0, t} \quad$ respectively. $P_{i, t}$ represents the monthly closing prices of stock $i$ at time $t$ while $P_{0, t}$ represents the monthly opening prices of stock 0 at time $t$. The returns of market portfolio are calculated based on equally weighted portfolio of all companies in each sector classification. 


\section{Empirical Results}

4.1 Descriptive Statistics

Table 1: Descriptive Statistics of Average Monthly Returns of Sectors and Cross-Sectional Returns Dispersion

\begin{tabular}{|c|c|c|c|c|}
\hline \multicolumn{5}{|c|}{ Panel 1: Average Monthly Returns of Portfolio } \\
\hline Sectors/Descriptive Statistics & Consumer Goods & Financial Services & Health Care & Industrial Goods \\
\hline Mean & 0.051429 & 0.025258 & 0.026852 & 0.029765 \\
\hline Median & 0.017298 & 0.008126 & -0.007899 & 0.011581 \\
\hline Maximum & 1.811897 & 0.620376 & 0.929855 & 0.744273 \\
\hline Minimum & -0.187245 & -0.327345 & -0.199336 & -0.194649 \\
\hline Std. Dev. & 0.200081 & 0.091286 & 0.130037 & 0.110877 \\
\hline Skewness & 6.442391 & 2.295593 & 3.012769 & 3.564832 \\
\hline Kurtosis & 50.00723 & 16.01462 & 17.10280 & 20.20103 \\
\hline Jarque-Bera & 17817.73 & 1428.445 & 1763.970 & 2600.306 \\
\hline Probability & 0.000000 & 0.000000 & 0.000000 & 0.000000 \\
\hline Sum & 9.257258 & 4.546487 & 4.833437 & 5.357671 \\
\hline Sum Sq. Dev. & 7.165813 & 1.491619 & 3.026832 & 2.200572 \\
\hline Observations & 180 & 180 & 180 & 180 \\
\hline $\mathrm{N}$ & 97 & 97 & 97 & 97 \\
\hline \multicolumn{5}{|l|}{ Panel 2: CSAD } \\
\hline Mean & 0.168824 & 0.121170 & 0.140308 & 0.131684 \\
\hline Median & 0.097935 & 0.081651 & 0.101700 & 0.095724 \\
\hline Maximum & 3.534945 & 0.769848 & 1.354173 & 1.175693 \\
\hline Minimum & 0.019567 & 0.019531 & 0.021801 & 0.021635 \\
\hline Std. Dev. & 0.364291 & 0.113152 & 0.143894 & 0.134279 \\
\hline Skewness & 7.021050 & 2.687337 & 4.418357 & 4.259851 \\
\hline Kurtosis & 56.69280 & 12.58732 & 32.10475 & 27.32703 \\
\hline Jarque-Bera & 23100.73 & 906.0281 & 6938.806 & 4982.923 \\
\hline Probability & 0.000000 & 0.000000 & 0.000000 & 0.000000 \\
\hline Sum & 30.38836 & 21.81053 & 25.25540 & 23.70313 \\
\hline Sum Sq. Dev. & 23.75466 & 2.291784 & 3.706299 & 3.227522 \\
\hline Observations & 180 & 180 & 180 & 180 \\
\hline $\mathrm{N}$ & 97 & 97 & 97 & 97 \\
\hline
\end{tabular}

Table 1 summarized the descriptive statistics respectively for average monthly market returns and dispersion returns of market portfolio. The average monthly returns of market portfolio range from a minimum incremental rate of 0.02 for the three sectors except for consumer goods with a maximum of 0.05 . The average monthly return volatility varies between a maximum of 0.20 for Consumer goods sector to a minimum of 0.09 for Financial services sector. The observations on Table 1 show that Consumer goods sector show higher variations of $20 \%$ compared to the other sectors; nevertheless, the percentage of these variations are still negligible.

The descriptive statistics of CSAD for the sectors show mean values of $0.16,0.12,0.14$, and 0.13 for Consumer goods, Financial services, Health care and Industrial goods respectively showed that Consumer goods sector has the highest mean value, followed by Health care, then Industrial goods and Financial services. These results depict that consumer goods sector has the highest market variation across industrial returns compared to others. The values of the standard deviation compared to the mean values of some of the sectors show that these sectors do not experience unusual variations, except for Consumer goods compared to their mean values. Thus, showing that Consumer goods experienced unusual variation due to unexpected news or shocks. This decision was reached based on the work of Chiang and Zheng (2010) which says that a higher mean value suggests significantly higher market variations across industrial returns for one industry compared to others, while a higher standard deviation suggests that the market had unusual cross-sectional variation due to unexpected news or shocks. 


\subsubsection{Graphical Presentation of Monthly Market Returns}

FS

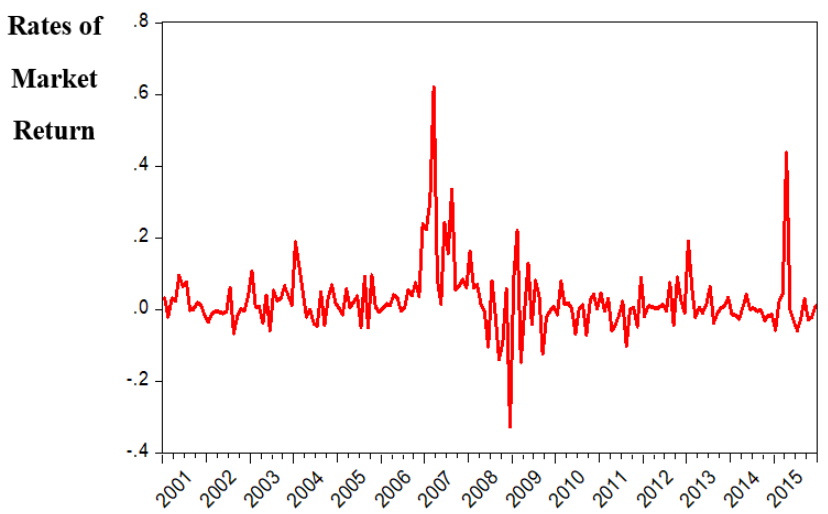

Years

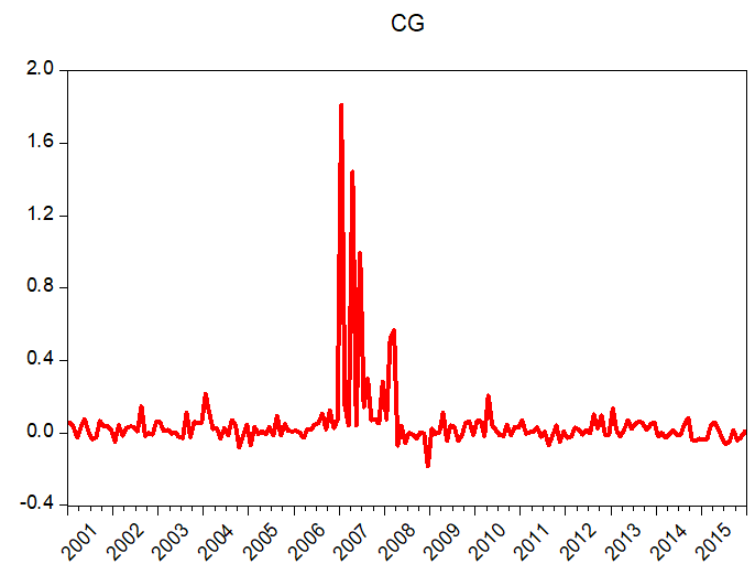

Fig. 2

HC
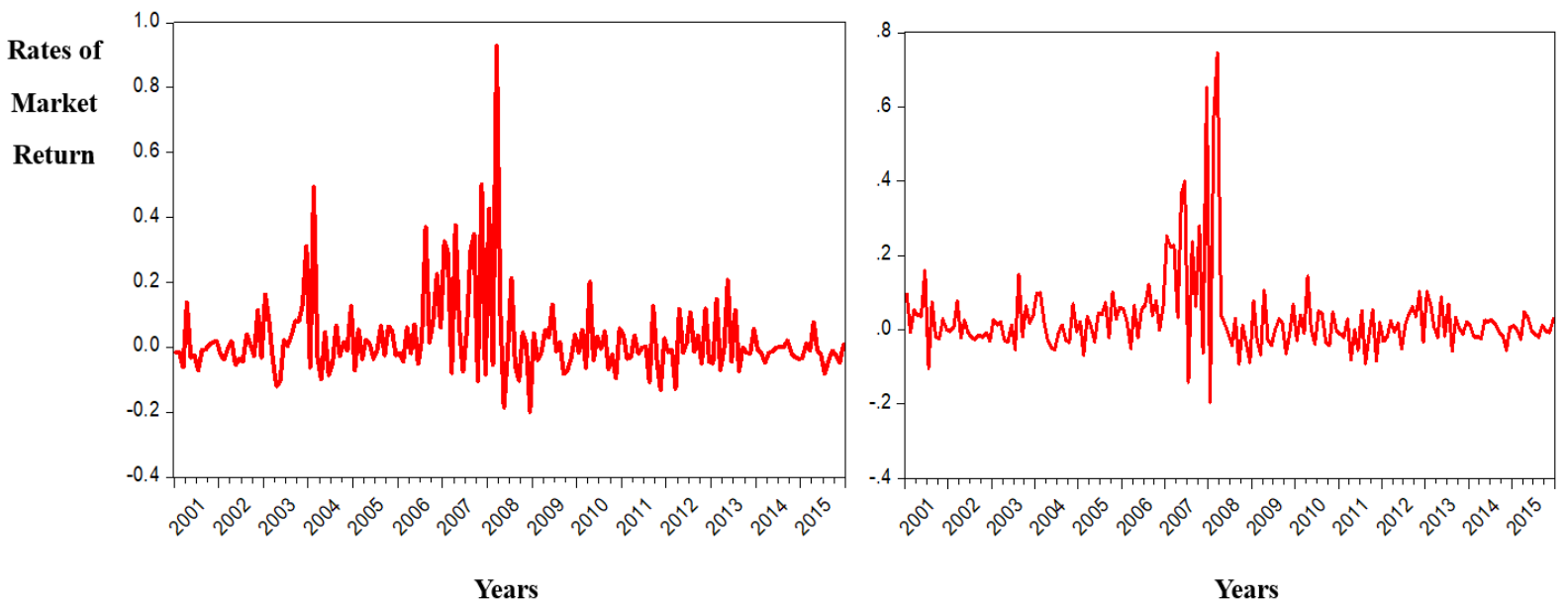

Fig. 3

Fig. 4

Figure 1-4: Individual Monthly Movement of Market Returns of the Four Sectors

The movement of market returns of each sector is further examined graphically to show how the returns move for the period of fifteen years. Figure 1 to Figure 4 showed that there was a high rate of change in returns noticed by all the sectors in early 2007. This could be as a result of change of government in Nigeria which took place in May, 2007. A change of government may either increase or decrease the stock price since the expectations of investors will also change. Considering the rate of increase experienced at the early months of 2007, one can attribute it to positive expectation from the in-coming then government and its impact on the stock market. Observing these graphs again, most of the sectors experienced a serious crash between late 2007 and 2008 . The returns fluctuated greatly and dropped greatly till late 2009 for most of the sectors. This observation could be traced to the global financial meltdown of $2007-2008$. 


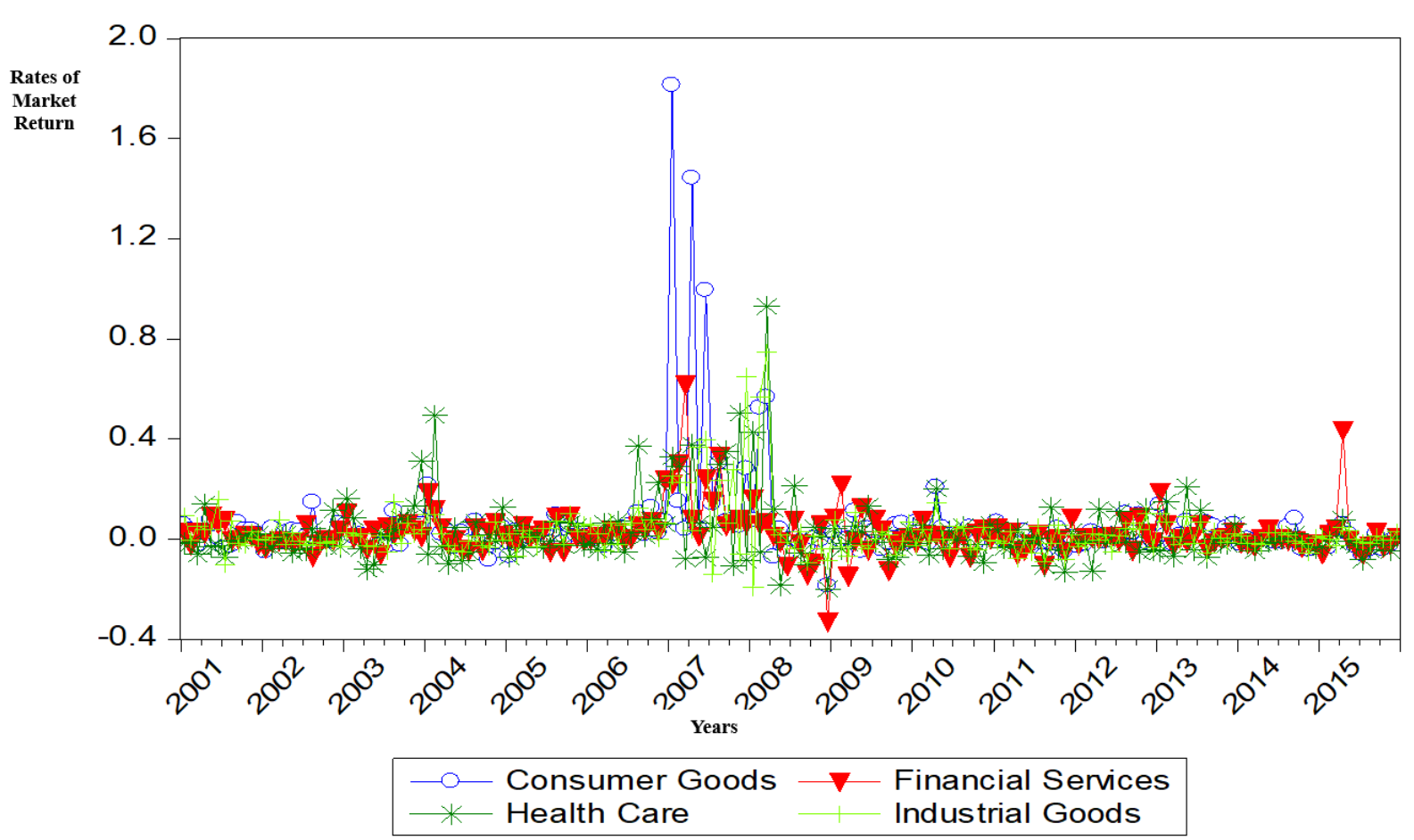

Fig. 5: Comparative Monthly Movement of Market Returns of the Four Sectors

A comparative view of the four sectors together was shown on Figure 5. It showed that at the early 2007, consumer goods sector experienced the most increase in market return which showed that due to the anticipated change of government, investors bought more stocks from consumer goods sectors compared to other sectors.

\subsection{Regression Results}

Table 2: Estimates of Herding Behaviour in Period of High/Low Price Volatility

\begin{tabular}{|l|l|l|l|l|l|l|}
\hline Sectors & Constant & $\mathbf{D}^{\mathbf{H v o l a t i l i t y}}\left|\mathbf{R}_{\mathbf{m}, \mathbf{t}}\right|$ & $\left(\mathbf{1}-\mathbf{D}^{\mathbf{H v o l a t i l i t y}}\right)\left|\mathbf{R}_{\mathbf{m}, \mathbf{t}}\right|$ & $\mathbf{D}^{\text {Hvolatility }} \mathbf{R}_{\mathbf{m}, \mathbf{t}}$ & $\begin{array}{l}(\mathbf{1} \\
\mathbf{R}_{\mathbf{m}, \mathbf{t}}\end{array}$ \\
\hline Consumer & 0.0484 & $1.5222^{* * *}$ & $1.6476^{* * *}$ & $0.2245^{* * *}$ & $0.1549^{* * *}$ \\
Goods & $(0.0000)$ & $(0.0000)$ & $(0.0000)$ & $(0.0000)$ & $(0.0000)$ \\
\hline Financial & 0.0511 & $1.4010^{* * *}$ & $1.5779^{* * *}$ & $-0.3340^{* * *}$ & $-1.0608^{* * *}$ \\
Services & $(0.0000)$ & $(0.0000)$ & $(0.0000)$ & $(0.0000)$ & $(0.0000)$ \\
\hline Health & 0.0631 & $0.8704^{* * *}$ & $1.0358^{* * *}$ & $0.4680^{* * *}$ & $0.4088^{* * *}$ \\
Care & $(0.0000)$ & $(0.0000)$ & $(0.0000)$ & $(0.0000)$ & $(0.0000)$ \\
\hline Industrial & 0.0592 & $1.2083^{* * *}$ & $1.1587^{* * *}$ & $0.0626^{*}$ & $0.2725^{* * *}$ \\
Goods & $(0.0000)$ & $(0.0000)$ & $(0.0000)$ & $(0.2531)$ & $(0.0046)$ \\
\hline
\end{tabular}

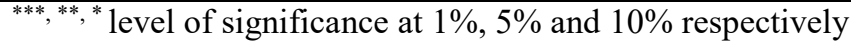

The values in the parentheses () are p-value

Table 2 showed the estimated results of the possible effect of price volatility on herding behaviour for all the four sectors are shown. The coefficients of a non-linear market return during high and low volatility showed a negative sign of -0.33 and -1.06 for Financial Services, while other sectors showed positive signs. This imply that during high and low volatility, Financial service showed evidence of herding behaviour, but the level of herding was not statistically significance, while herding was not noticed in the other three sectors. The p-values of almost all the sectors were lower than 0.05 level of significance, except for Industrial goods $(0.25)$ during high price volatility. This implied that price volatility had effect on herding behaviour in all the three sectors, but did not have in Industrial goods sector during high price volatility.

These findings contradicted the work of Ouarda, et al. (2013) who discovered high level of herding behaviour in Financial services during low volatility, and also some levels of herding in the other three sectors of European market during high volatility.

\section{Conclusion}

The purpose of this paper was to empirically study the existence of herding behaviour during price volatility in four sectors of the Nigerian stock exchange for a period of 15 years, that is, from January 2001 to December 2015. For the different sectors identified, the study showed empirical evidences in support of the existence of herding 
behaviour that is not statistically significant during price volatility only in Financial services sector, while evidence of herding behaviour was not noticed in the remaining three sectors. In the stock market, it is theoretically believed that the presence of any market condition would influence investors' behaviour, but this study has shown that the influence of price volatility on herding behaviour did not determine significant level of herding in any of the sectors. It is therefore concluded that price volatility influences herding behaviour, but the influence did not determine significance level of herding in any of the sectors. The study recommended that the existence of herding in Financial services sector should be investigated and NSE should also make all information available to all market participants in order to boost their confidence in making investment decisions since information is regarded as power and a well-informed investor has an edge over others.

\section{References}

Ahsan, A. F. M. \& Sarkar, A. H. (2013). Herding in Dhaka stock exchange. Journal of Applied Business and Economics, 14(2): 11-19.

Chang, E.C., Cheng, J.W. \& Khorana, A. (2000). An examination of herd behaviour in equity markets: An international perspective. Journal of Banking and Finance, 24(10): 1651-1679.

Chiang, T. C. \& Zheng, D. (2010). An empirical analysis of herd behaviour in global stock markets. Journal of Banking \& Finance, 34(8): 1911-1921.

Christie, W.G. \& Huang, R. D. (1995). Following pied piper: do individual returns herd around the market? Financial Analysts Journal, 51(4): 31-37.

Demirer, R. \& Kutan, A. (2006). Does herding behaviour exist in Chinese stock markets? Journal of International Financial Markets, Institutions and Money, 16(2): 123-142.

Friedman, M. (1953). "The Case for Flexible Exchange Rates," in Milton Friedman (ed.), Essays in Positive Economics, University of Chicago Press, Chicago, IL.

Ganesh, R. \& Naresh, G. (2016). Industry herding behaviour in India stock market. American Journal of Finance and Accounting, 4(3-4): 284-308.

Gleason, K.C., Mathur, I. \& Peterson, M.A. (2004). Analysis of intraday herding behaviour among the sector ETFs. Journal of Empirical Finance, 11(5): 681-694.

Kahneman, D. \& Tversky, A. (1979). Prospect theory: an analysis of decision under risk. Econometrica, 47(2): 263-292.

Kim, C., Lee W., Choi, Y.H. \& Ahn, J.Y. (2013). Analyzing herd behaviour in global stock markets: An intercontinental comparison. Retrieved February 23, 2015 from http://arxiv.org/pdf/1308.3966.pdf

Lakonishok, J., Shleifer, A. \& Vishny, R.W. (1992). The impact of institutional trading on stock prices. Journal of Financial Economics, 32(1): 23-43.

Lakshman, M. V., Basu, S. \& Vaidyanathan, R. (2013). Market wide herding and the impact of institutional investors in the Indian capital market. Journal of Emerging Market Finance, 12(2): 197 - 237.

Lao, P. \& Singh, H. (2011). Herding behaviour in the Chinese and Indian stock markets. Journal of Asian Economics, 22(6): 495-528.

Ohiomu, S. \& Enabulu, G. O. (2011). The effect of stock market on economic growth in Nigeria. Journal of Research in National Development, 9(1): 287 - 295.

Oseni, E. \& Olanrewaju. R.O. (2017). A capital asset pricing model's (CAPM's) beta estimation in the presence of normality and non-normality assumptions. International Journal of Finance and Banking Research. 3(3): $44-52$.

Ouarda, M., Abdelfatteh, E.B. \& Olivero, B. (2013). Herding behaviour under markets condition: Empirical evidence on the European financial markets. International Journal of Economics and Financial Issues, 3(1): 214-228.

Perold, A. F. (2004). The capital asset pricing model. Journal of Economic Perspectives, 18(3): 3-24.

Prosad, J., Kapoor, S. \& Sengupta, J. (2012). An examination of herd behaviour: an empirical study on Indian equity market. International Conference on Economics and Finance Research, 32: 11-15.

Rossi, M. (2016). The capital asset pricing model: a critical literature review. Global Business and Economics Review, 18(5): $604-617$.

Tran, N.M. \& Huy, H.T. (2011). Herding behaviour in an emerging stock market: empirical evidence from Vietnam. Research Journal of Business Management, 5(2): 51-76.

Walter, A. \& Weber, F.M. (2006). Herding in the German mutual fund industry. European Financial Management, 12(3): 375-406.

Wang, J. (1993). “A Model of intertemporal asset prices under asymmetric information,” Review of Economic Studies, 60: 249-282.

Yadav, S. (2017). Stock market volatility: a study of Indian stock market. Global Journal for Research Analysis, 6(4): 629-632. 